УДК: 94(410)

ББК: 63.3(0)52

\title{
Кризис в заливе Нутка 1790 г.: англо-испанское противостояние
}

\author{
А.А. Куницын
}

Московский педагогический государственный университет (Москва, Россия)

\section{Anglo-Spanish Confrontation in the Nootka Sound in 1790}

\author{
A.A. Kunitsyn
}

Moscow Pedagogical State University (Moscow, Russia)

В статье рассматривается малоизученный в отечественной историографии эпизод англо-испанских отношений: территориальный спор Лондона и Мадрида вокруг залива Нутка, расположенного на о. Ванкувер у западного побережья Канады, в 1790 г. Стремительно развивающиеся события вокруг малоизученного залива и неуступчивость двух держав поставили страны на грань полноценной войны. В это противостояние были втянуты и их союзники - Голландия и Франция. Однако Франция, ослабленная революцией, не смогла выполнить свои союзнические обязательства. Кроме того, англоиспанский конфликт усилил внутренний разлад в Париже. Все это привело к тому, что испанский двор был вынужден отказаться от каких-либо претензий на залив. Заключив в 1794 г. конвенцию, Англия и Испания взаимно отказались от какихлибо суверенных прав на залив, тем самым объявив его свободным для доступа подданных обеих держав. Нуткинская конвенция ознаменовала собой отказ от принципов обладания территорией по праву открытия, что впоследствии привело к изменению характера колониальной политики мировых держав и к их ожесточенному противостоянию в колониях во второй половине XIX в.

Ключевые слова: Великобритания, Испания, начальный этап Французской революции 1789 г., залив Нутка, колониализм, международные отношения.

DOI 10.14258/izvasu(2019)5-10

Историография проблемы англо-испанского противостояния из-за залива Нутка в 1790 г. представлена в основном работами английских и американских историков, опубликованных в различных журналах в XX в. [1-4]. В наши дни кризис, порожденный этой борьбой, изучают прежде всего канадские исследователи в рамках истории Британской Колумбии и освоения западных территорий Канады [5; 6]. В современ-
The article discusses an insufficiently studied episode in Russian historiography in Anglo-Spanish relations: the territorial issue in 1790 between London and Madrid in the Nootka Sound that located on Vancouver Island off the West coast of Canada. Rapidly developing events around the Nootka Sound and the intransigence of the two powers set the country on the brink of a fullfledged war. The allies of the countries - Holland and France were also involved in this confrontation. However, France, weakened by the revolution, was unable to fulfill its allied obligations. In addition, the Anglo-Spanish conflict intensified the internal conflict in Paris. All this resulted the Spanish court being forced to give up any claim to the Sound. In the Convention concluded in 1794 England and Spain mutually renounced their sovereign rights to the Sound, there by declared it free for access by the subjects of both powers. Thus, the Nootka Convention marked the abandonment of the principles of possession of territory by right of discovery, which subsequently led to a change in the nature of the colonial policy of the world powers, and to their fierce confrontation in the colonies in the second half of the $19^{\text {th }}$ century.

Key words: Great Britain, Spain, the initial stage of the French revolution of 1789, Nootka Sound, colonialism, international relations. ной отечественной историографии вопрос о кризисе в заливе Нутка остается малоизученной и плохо освещенной темой. Данная статья призвана заполнить эту лакуну, одновременно поставив новые проблемы в изучении международных отношений конца XVIII в. и истории колониализма XIX в.

В последней четверти XVIII в. северо-западное побережье Америки все еще оставалось малоиссле- 
дованным регионом на карте мира, и одновременно изучалось как английскими, так и французскими и испанскими путешественниками.

В декабре 1788 г. вице-король Новой Испании М. Флорес Мальдональдо отправил капитана Э.Х. Мартинеса Фернандеса к заливу Нутка с целью основать там поселение и формально закрепить эти земли за испанской короной. Однако капитан действовал более решительно: английские корабли, прибывавшие в залив, конфисковывали вместе с грузом, а команды зачастую подвергали аресту. 24 июня 1789 г. Мартинес Фернандес официально провозгласил испанской территорией все побережье Америки от мыса Горн до 60-й параллели северной широты. Территории, расположенные севернее, признавались российскими [7, p. 233]. Прибывшие в залив британские шлюпы «Царственная принцесса» (Princess Royal) и «Аргонавт» были арестованы. «Аргонавт» имел на борту строительные материалы и китайских рабочих. Груз был конфискован, а рабочих испанцы заставили строить укрепления в заливе.

Первые противоречивые слухи об этом инциденте достигли Лондона в январе 1790 г. в депешах британского поверенного в делах в Мадриде Э. Мерри [2, p. 562]. В Лондоне смутно представляли, что именно произошло в Америке, Кабинет ожидал более подробных новостей. 11 февраля посол Испании маркиз дель Кампо представил записку британскому правительству, в которой пролил свет на инцидент. Посол, ссылаясь на Тордесильясский договор 1494 г. между Испанией и Португалией о разделе сфер влияния, настаивал на том, что вооруженный британский корабль «Аргонавт» под руководством капитана Дж. Колнетта и шлюп «Царственная принцесса» прибыли в залив уже после того, как Фернандес провозгласил эту территорию испанскими владениями [8, p. 9-10]. Лондонский кабинет сомневался в законности испанских притязаний, однако не желал портить отношения с мадридским двором. Спустя две недели Ф. Осборн герцог Лидс ответил дель Кампо. Британский министр настаивал на том, что дальнейшее обсуждение претензий и прав на побережье может быть продолжено лишь после полной компенсации британским торговцам за потерянное имущество и удовлетворения за оскорбление британского флага [2, р. 563-564]. Однако вскоре пришли донесения от Мерри из Мадрида о том, что Испания наращивает военное присутствие в Америке. Кроме того, в Лондоне стало известно, что Испания отправила своим послам инструкции о начале переговоров по поводу организации союза Парижа, Вены, Петербурга и, возможно, Копенгагена против Англии и Пруссии, обвиняя Лондон в том, что вместо мира Британия хотела войны и «ухватилась за жалкий предлог Нутки, чтобы осуществить это» (цит. по: [3, p. 613]).
В апреле 1790 г. в Англию вернулся лейтенант Д. Миарес, занимавшийся торговлей мехом в заливе под флагом Макао в обход монополии Ост-Индской компании. В письме к министру внутренних дел У. Гренвиллу он подтвердил самые тревожные слухи о произошедшем. Кроме того, лейтенант утверждал, что купил эти земли в заливе у вождя народа Нутки Маквина, но позже сам вождь отрицал этот факт [9, р. 198]. На полученной земле, по словам Миареса, он построил дом и планировал организовать пост для торговли по всему побережью. Лейтенант просил правительство добиться компенсации у испанской стороны за причиненный ему ущерб. Чуть позже это письмо было опубликовано в «The Gentleman's Magazine», и события в мало кому известном заливе стали достоянием общественности, настроив большую часть британцев на войну с Испанией [10, p. 487-490].

1 мая 1790 г. был отдан приказ о мобилизации английского флота, началась подготовка к экспедиции. Герцог Лидс постоянно отмечал, что экспедиция имеет лишь оборонительный характер, и в письмах к Мерри писал, что флот предназначается для защиты британских подданных «от дальнейших посягательств» со стороны испанцев и поддержки переговоров по Нутке [7, p. 236]. В письме от 4 мая он поместил официальное заявление Лондона: «Британские подданные, торгующие под защитой британского флага... имеют неоспоримое право на свободное и беспрепятственное пользование благами торговли, судоходства и рыболовства [в Тихом океане], а также [на] владение учреждениями, какие они могут образовать, с согласия местного населения в местах, не занятых другими европейцами» (цит. по: [5, p. 168]).

5-6 мая 1790 г. в Палате общин проходили дебаты по поводу этой меры. Премьер-министр У. Питт Младший, принципиально выступавший против фритредерства, не хотел поддерживать претензии Миареса. Но ему пришлось уступить, чтобы в преддверии выборов не дать вигам лишнего повода для нападок на правительство. Лидер вигской оппозиции Ч.Дж. Фокс поддержал идею противостояния «одинаково несправедливым и необоснованным требованиям испанского двора", однако считал, что Британия должна также бороться за компенсации для купцов и «предотвращение подобных инцидентов в будущем» $[11$, p. 13-14]. Он отмечал, что дело не в захвате британских кораблей, а в притязаниях испанского двора на Америку, следовательно, он надеялся, что Англия «не только получит компенсацию за нанесенный ущерб, но и добьется отказа [Испании] от притязаний, выдвинутых на таких незначительных основаниях» [11, p. 14-15].

Война уже стояла на пороге. Испания надеялась на поддержку Франции, с которой ее объединял Фамильный пакт испанской и французской ветви Бурбонов. Объединенный франко-испанский флот 
был значительно больше английского, и в случае конфликта Лондон мало что смог бы ему противопоставить. В мае в союзную Голландию отправился У. Иден барон Окленд, чтобы договориться со штатгальтером Вильгельмом V Оранским об использовании голландских кораблей в случае конфликта. Ему удалось добиться того, что 10 линейных кораблей перейдут под английское командование. Взамен Англия была обязана выплатить Голландии от 29 тыс. (за один месяц службы) до 52 тыс. ф. ст. (за три месяца службы). В случае необходимости союзник мог удвоить число кораблей на тех же условиях [8, p. 97-98].

Весь май 1790 г. прошел в ожидании решения Парижа. Французская аристократия настаивала на немедленном исполнении условий пакта. 14 мая Людовик XVI отдал приказ подготовить линейные корабли [7, p. 239]. Французский министр иностранных дел граф А.М. де Монморен рассчитывал, что угроза со стороны заклятого врага Франции способна сплотить страну вокруг трона. В беседе с русским послом И.М. Симолиным он заявлял, что «уверен в стремлении британского кабинета затеять ссору с Испанией и объявить ей войну, которую надеются легко довести до конца, ввиду невозможности для Франции помогать Испании» [12, с. 430]. В целом, против Лондона было настроено все Национальное собрание, однако его порыв компенсировался нежеланием содействовать монархическому союзу с Испанией. Кроме того, «третье сословие» считало, что под предлогом войны с Лондоном король желал лишь увеличить вооруженные силы и обратить их против Национального собрания [13, с. 411]. В связи с этим многие депутаты настаивали на лишении короля полномочий в вопросах войны и мира. Тем самым внешнеполитический вопрос перерос во внутриполитический, еще более усугубив противоречия внутри Франции. Дебаты в Национальном собрании с 14 по 22 мая по вопросу Фамильного пакта, несмотря на давление на Монморена со стороны государственного секретаря Испании Х.М.-и-Р. Флоридабланка и испанского посла герцога Фернана Нуньеса, не принесли результатов. Париж медлил с ответом, и инициатива перешла к Англии.

В Лондоне также ждали решения Парижа. Однако многие политики во главе с Лидсом желали получить от Испании «безоговорочное удовлетворение оскорбления» и считали, что война неизбежна, призывая Питта к активным действиям [3, p. 615]. Питт еще надеялся на компромиссное решение. В мае на пост посла в Мадриде был назначен А. Фитцгерберт. Кроме того, в Париж были отправлены агенты У. Майлз и Х. Эллиот. Одним из условий их действий, выдвинутым королем Георгом III, было невмешательство «во внутренние разногласия Франции» $[14$, p. 201]. Ярый франкофил и сторонник револю- ции Майлз должен был воспользоваться своими связями в Париже и склонить Национальное собрание к мнению о том, что династический союз с Мадридом уже невыгоден стране [3, p. 619].

В начале июня из Лондона Фитцгерберту были отправлены указания: предъявить испанцам ультиматум с требованием безоговорочной компенсации за оскорбления, нанесенные английской стороне, который был вручен Флоридабланке 5 июля [2, p. 575]. К этому времени испанский двор начал сомневаться, что Франция выполнит свои обязательства по Фамильному пакту. Испанский министр попрежнему настаивал на правомерности действий в Нутке, однако без поддержки Франции Мадрид не мог рассчитывать на успех в войне. Фитцгерберт писал в депеше Лидсу от 21 июля: «Теперь цель Испании - мир любой ценой» [14, p. 200]. 24 июля 1790 г. Флоридабланка был вынужден подписать декларацию, в которой соглашался на полную компенсацию ущерба Англии. Новость об этом достигла Лондона 5 августа, и во всей стране праздновалась как великая победа британской дипломатии. Георг III писал У. Гренвиллу о том, что «благодарит Всевышнего, за то, что он предотвратил катастрофу, и как бы почетно это (вести войну. - А.К.) ни было, но введение новых налогов могло бы показать, что страна не в состоянии вести войну, и это вызвало бы недовольство... населения» [15, р. 603-604].

Вскоре был подготовлен текст договора, по которому Испания возвращала все конфискованное имущество британских подданных и гарантировала равные права на промысел в Тихом океане за пределами десяти лиг от побережья. Кроме того, договор предусматривал переговоры об ограничении колонизации побережья Северной Америки для Испании и по созданию буферной зоны, на которой ни Испания, ни Англия не могли возводить поселения, за исключением риска появления в этой зоне поселений третьей стороны [8, p. 168-171].

Но радость в Англии от очередной дипломатической победы продолжалась недолго. Дипломатический комитет Национального собрания Франции решил преобразовать Фамильный пакт в Национальный, тем самым обещав поддержку Испании в случае оборонительной войны. В Лондоне были не против этого решения, однако серьезную озабоченность вызвало намерение Парижа мобилизовать 45 линейных кораблей. Несмотря на то, что этот флот мог представлять угрозу, английский посол написал 27 августа из Парижа, что Франция не обладает необходимыми средствами для ведения войны [16, с. 55]. Лидс отправил Фитцгерберту инструкции, в которых просил сообщить испанскому двору, что «интервенция Франции не заставит нас отказаться ни от одного пункта наших нынешних предложений» [3, p. 623]. 
В сентябре Монморен отправил инструкции французскому послу в Лондоне Эну-Сессару маркизу де ла Люцерну, в которых послу давалось поручение объявить Лидсу и Питту, что это лишь мера предосторожности, а король Франции надеется на быстрое и справедливое разрешение конфликта. При этом Монморен просил обратить внимание на то, что на мобилизации 45 кораблей настаивало Национальное собрание, хотя правительство просило лишь о 30 кораблях. В личном письме Люцерну он отметил, что, несмотря на готовность испанского короля предоставить Англии компенсацию, последняя все еще продолжала вооружаться, поэтому в Париже невольно заподозрили скрытые намерения, которые, вероятно, касались Франции [4, p. 163-164].

15 августа 1790 г. в Мадриде отказались от британского проекта договора, сославшись на то, что вопрос о доступе к побережью для английских рыбаков может быть рассмотрен после решения о статусе залива Нутка [7, p. 249]. Однако Флоридабланка неожиданно сообщил Фитцгерберту, что король не хочет заменять Фамильный пакт с Францией Национальным, он более склонен делать ставку на союз с Великобританией нежели с Францией. Испанский министр был готов предложить Лондону систему союзов, которая бы позволила Мадриду избежать заключения пакта с Францией [3, p. 623-624].

Трудно с уверенностью сказать, был ли испанский министр искренен с послом. Вероятно, мадридский двор начал осознавать опасность коренных перемен в Париже, поэтому старался отдалиться от происходящих там событий. Английский историк сэр Дж.Г. Клэпхэм настаивал, что «Испания никогда не хотела альянса только на тех условиях, которые рассматривали во Франции» [14, р. 201]. Однако, несмотря на все заверения Фитцгерберта, Питт и Лидс отказались от предложения Флоридабланка и выдвинули ультиматум о принятии им в течение 10 дней первоначальных английских условий. В Карибское море были посланы английские корабли.

Предложение Флоридабланка дало понять английскому кабинету, что мадридский двор и Париж действуют независимо друг от друга [4, p. 171]. В сентябре активизировались «агенты Питта» в Париже Майлз и Эллиот. Еще в мае 1790 г. посол Симолин доносил в Петербург: «Здесь почти все предполагают, что Англия имеет в Национальном собрании подкупленных ею и преданных ее интересам секретных агентов» [12, с. 430]. Используя свои связи среди якобинцев, Майлзу удалось склонить их к мнению, что Франции невыгодно вступать в войну. Эллиот был старым школьным приятелем видного деятеля революции О.-Г. Рикетти маркиза де Мирабо. Вероятно, не без «английского золота», о котором ходило много слухов в те дни в Париже, ему удалось склонить его и его сторонников на позицию невме- шательства в возможный англо-испанский конфликт, по словам самого Мирабо, «за клочок земли, который фактически не принадлежит ни одной из них» $[11$, p. 80]. Единственной силой, кроме монархистов во главе с Монмореном, желавшей поддержать Испанию в войне с Англией, была группа сторонников М.-Ж. дю Мотье маркиза де Лафайета, давнего и убежденного противника Лондона [3, p. 627].

Но конфликт так и не разгорелся. 28 октября 1790 г. испанский министр решил уступить и подписал договор на британских условиях. Угроза масштабной войны исчезла. Для французских монархистов это стало полной неожиданностью. Помимо того, что Испания отказалась подписывать Национальный пакт, ее договор с Англией закрывал Парижу доступ на северо-западное побережье Америки. Фактически Лондон спровоцировал разрыв союзных отношений между двумя колониальными державами, что впоследствии могло облегчить Британии укрепление собственных позиций в Ост- и Вест-Индии. Именно это в итоге привело к тому, что сторонники нормализации отношений с Лондоном в Париже перестали доверять Англии.

Однако переговоры о разграничении земель и прочих условиях договора продолжались еще долго. С вступлением Англии и Испании в войну с Францией в 1793 г. страны стали союзниками, поэтому спор потерял свою актуальность. Окончательно территориальный вопрос разрешился только в 1794 г., когда страны подписали Конвенцию о взаимном отказе от Нутки, по которой залив объявлялся свободным для подданных обеих стран, которым разрешалось там необходимое строительство. Обе державы отказывались требовать друг от друга какого-либо суверенитета над этой территорией, при этом совместно не допускать туда представителей других держав [6, p. 164-165]. В 1795 г. в залив прибыли испанский полковник Х.М. де Алава и британский лейтенант Т. Пирс. Алава спустил испанский флаг в заливе, а Пирс поднял и спустил британский флаг. Флаги были переданы вождю Маквина, который должен был поднимать их при появлении кораблей в заливе [6, p. 166].

В историческом контексте Нуткинские соглашения подрывали сложившееся представление о том, что какая-то нация может претендовать на земли «по праву открытия». Для этого теперь оказалась необходима организация постоянного поселения, что официально будет закреплено лишь в 34 и 35 статьях постановления Берлинской конференции по вопросам раздела Африки в 1875 г. По мнению американского историка Дж. Симсариана, Нуткинские соглашения повлияли на характер колониальной политики всего XIX в. [17, p. 127]. Компромиссное решение конца XVIII в. заложило основы ожесточенного противостояния европейских держав в Африке во второй половине XIX в. и в масштабной Первой мировой войне уже в начале XX в. 


\section{Библиографический список}

1. Manning W.R. The Nootka Sound Controversy // American Historical Association Annual Report. 1905.

2. Norris J.M. The Policy of the British Cabinet in the Nootka Crisis // The English Historical Review. Vol. 70, Issue 367, 1955. DOI: 10.1093/ehr/LXX.CCLXXVII.562.

3. Evans H.V. The Nootka Sound Controversy in AngloFrench Diplomacy-1790 // The Journal of Modern History. Vol. 46, № 4, 1974. DOI: 10.1086/241265.

4. Blue G.V. Anglo-French Diplomacy during the Critical Period of the Nootka Controversy, 1790 // Oregon Historical Quarterly. Vol. 39, № 2, 1938.

5. Clayton D. Islands of Truth: The Imperial Fashioning of Vancouver Island. Vancouver, 2000.

6. Gough B.M. The Northwest Coast: British Navigation, Trade and Discoveries to 1812. Vancouver, 2011.

7. Black J. British Foreign Policy in an Age of Revolutions, 1783-1793. Cambridge, 1994.

8. Burges J.B. A Narrative of the Negotiations Occasioned by the Dispute between England and Spain in the Year 1790 [L., 1791].

9. Dictionary of National Biography. Vol. XXXVIII. L., 1894.
10. The Gentleman's Magazine. Vol. 60. L., 1790.

11. Official Papers Relative to the Dispute between the Courts of Great Britain and Spain on the Subject of the Ships Captured in Nootka Sound and the Negotiation that Followed thereon. L., 1790.

12. Французская революция 1789 г. в донесениях русского посла в Париже И.М. Симолина // Литературное наследство. Т. 29-30. М., 1937.

13. Нарочницкий А.Л. Европейская дипломатия в годы Французской буржуазной революции 1789-1794 гг. // История дипломатии. 2-е изд. Т. І. М., 1959.

14. Clapham J.H. Pitt's First Decade, 1783-1792 // The Cambridge History of the British Foreign Policy. Vol. I.1922.

15. Fortescue J.B. The Manuscripts of J.B. Fortescue Preserved at Dropmore. Vol. I. L., 1892.

16. Тимофеев П.В. Дипломатия Франции и образование I антифранцузской коалиции в 1789 - начале 1793 г. : дис. ... канд. ист. наук. Брянск, 2006.

17. Simsarian J. The Acquisition of Legal Title to Terra Nullius // Political Science Quarterly. Vol. 53, №1. 1938. DOI:10.2307/2143606. 